\title{
Process Mineralogy of Iranian High Sulfur Iron Ore
}

\author{
Tonglin Zhao1, Xiaoli Wang ${ }^{1}{ }^{*}$, Hongle Ai ${ }^{1}$, Ahmed Sobhy ${ }^{1,2}$ \\ ${ }^{1}$ College of Mining Engineering, University of Science and Technology Liaoning, Anshan, China \\ ${ }^{2}$ Central Metallurgical Research and Development Institute, Helwan, Cairo, Egypt \\ Email: 4795804@qq.com, ^20339859@qq.com
}

How to cite this paper: Zhao, T.L., Wang, X.L., Ai, H.L. and Sobhy, A. (2018) Process Mineralogy of Iranian High Sulfur Iron Ore. Journal of Minerals and Materials Characterization and Engineering, 6, 498506.

https://doi.org/10.4236/jmmce.2018.64035

Received: June 5, 2018

Accepted: July 21, 2018

Published: July 24, 2018

Copyright (c) 2018 by authors and Scientific Research Publishing Inc. This work is licensed under the Creative Commons Attribution International License (CC BY 4.0).

http://creativecommons.org/licenses/by/4.0/

\begin{abstract}
Processing of Iranian high sulfur iron ore is problematic in minerals industry. The iron ores were studied by the means of polarizing microscopy, chemical analysis, X-ray diffraction. The study shows that the iron ores have high grade of iron, and complex structures. XRD showed that the iron ore consists of metallic minerals such as magnetite with a small amount of hematite and limonite and non-metallic minerals as serpentine, chlorite, and talc. The average particle size of magnetite crystals is $0.182 \mathrm{~mm}$. The ore contains $1.62 \%$ sulfur as harmful impurity in form of pyrite mineral. Due to the isomorphism of magnesium and iron, magnetite mono crystal grade is lower than $68 \%$, and difficult to be physically upgraded to a higher-grade iron concentrate using the available mineral processing technologies.
\end{abstract}

\section{Keywords}

High-Sulfur Iron Ore, Process Mineralogy, Magnetite, Pyrite

\section{Introduction}

With the developed demands on mineral resources, the availability of easy-toupgrade ores are decreasing, and working on hard-to-separate ores became essential. The study of technological mineralogy is the basic work of mineral processing. Many researchers have carried out lots of related research about this work. Rao D. S. et al. carried out the study on the iron mine in Hospet by using microscope, XRD and so on [1]. Mhanhany J. K. and others discussed the importance of integrated mineralogical characterization in beneficiation of iron ores [2]. Mohanty J. and others studied the mineralogical properties of two low grade siliceous manganese ores in northern Orissa, India and its mineral processing technology and results [3]. Through the process mineralogy, the 
mineral composition, the content of element composition, the grain size and the occurrence state of the mineral were studied [4].

In southeast of Iran at the border of Root Plateau and Zagro large thrust belt, there is 2800 million tons deposit of iron ore with a relatively intensive distribution [5]. There are two ways for ore deposits output, one of which is layer, layer-like form along the amphibolite facies metamorphic rock series. The wall rocks always contain phosphorus limestone, tourmaline and brucite, and have the phenomenon of vertical zoning. The surface oxidation zones mainly contain limonite and hematite ores, and are gradually changed into martite zones and pure magnetite zones downward. The second output is along the volcanic bodies, the ore body of which is lenticular and columnar in volcanic rock and volcaniclastic rock. The border between ore body and wall rock is clear, and seldom with the crypto explosion. The ores are mainly apatite, pyrite and magnetite. The second kind of ore deposits is the main target to be exploited at present, while the first kind of ore deposits has high sulfur, hard-to-separate, and less to be exploited [6].

In this study, Both of as-mined and concentrate of the iron ore were extensively characterized by polarizing microscopy, chemical analysis, and X-ray diffraction in order to figure out the process mineralogy of Iranian high sulfur iron ore and to find a suitable upgrading procedure for this type of iron ore.

\section{Experimental}

\subsection{Material}

Iron ore samples were acquired from Golgohar mine in Iran. The deposit is Neoarchean-Paleoproterozoic volcanic-sedimentary metamorphic type iron ore. The basic reserve is about 2000 million tons with average iron grade of more than $50 \%$.

\subsection{Methods}

The ore was cut into pieces and polished on a polishing machine at first. Then the types, structures and mineral phase compositions of ore were characterized by conducting polarizing microscopy of Axioskop $40 \mathrm{~A}$ Pol, under which the mineral phase composition of ore was figured out, and the grain size was measured and counted by method of line segment.

The element compositions analysis was estimated by X-ray fluorescence spectrometer S8-TIGER. The samples of -74 um were compressed into slices with boric acid by a pressure prototype and then put into the X-ray fluorescence spectrometer to test.

The mono crystal minerals were made by shaking table gravity concentration with over $67 \%$ grade of magnetite concentrate at first. Then the concentrate was sampled on one side of the richest concentrate zone of shaking table. After that, the sample was concentrated again by hand, thus the mono crystal minerals were abtained. The mono crystal minerals composition was identified by X-ray dif- 
fraction analyzer $\mathrm{D} / \max 2500$. The XRD graph parameters of samples were compared with retrieval data of standard JCPDS database, thereby the phase compositions of the products were determined finally.

\section{Results and Discussion}

\subsection{Chemical Composition of the Ore}

There are more than ten kinds of minerals observed by microscopy. In as-received sample, the main valuable metallic mineral is magnetite with the content of $30 \%-45 \%$. The second is $1 \%$ to $8 \%$ pyrite and $5 \%$ limonite and hematite. The major non-metallic minerals are serpentine, chlorite and talc, seldom with brucite, phlogopite and carbonate minerals. The reason for high sulfur as harmful impurity in run-of-mined ore is the presence of pyrite. The elemental chemical analysis and mineral phase analysis results of run-of-mined ore are shown in Table 1 and Table 2 respectively.

It can be seen that the metallic mineral that can be recovered from run-ofmined ore is mainly magnetite, which is $86.82 \%$ of total iron in the ore. The ore contains $1.62 \%$ sulfur impurity; thus, the ore is considered as magnetite ore with high sulfur hard-to-upgrade.

\subsection{The Type and Structures of Ore}

\subsubsection{The Type of Ore}

The iron ore can be divided into two main types according to their mineral content, mixture association, and structures under single polarizing microscopy. One is sparsely disseminated magnetite ore shown in Figure 1 and Figure 2, in which the magnetite (the black part) appears to be middle-fine granular mono crystal or polycrystalline association texture such as idiomorphic crystal and sub-hederal crystal middle-fine granular texture; and fiber like plastic texture and metasomatic pseudomorph texture [7]. The second type is densely disseminated magnetite rich ore shown in Figure 3 and Figure 4, in which the magnetite appears to be middle-coarse granular texture, fiber like plastic texture [8].

The combination of magnetite and pyrite can be visible in the two ore types. In sparsely disseminated magnetite barren ore, the content of magnetite is

Table 1. Elemental chemical analysis of run-of-mined ore.

\begin{tabular}{cccccccccc}
\hline element & $\mathrm{TFe}$ & $\mathrm{FeO}$ & $\mathrm{SiO}_{2}$ & $\mathrm{Al}_{2} \mathrm{O}_{3}$ & $\mathrm{CaO}$ & $\mathrm{MgO}$ & $\mathrm{S}$ & $\mathrm{P}$ & Loss \\
\hline Mass fraction (\%) & 50.91 & 15.29 & 11.15 & 3.10 & 0.93 & 8.01 & 1.62 & 0.075 & 4.09 \\
\hline
\end{tabular}

Table 2. Mineral phase analysis of run-of-mined ore.

\begin{tabular}{cccccc}
\hline Mineral name & Total iron & $\begin{array}{c}\text { Magnetic } \\
\text { iron }\end{array}$ & $\begin{array}{c}\text { limonite and } \\
\text { hematite }\end{array}$ & pyrrhotite & pyrite \\
\hline Mass fraction of iron (\%) & 50.91 & 44.20 & 4.87 & 0.12 & 1.42 \\
Distribution rate of iron (\%) & 100.00 & 86.82 & 9.56 & 0.24 & 2.79 \\
\hline
\end{tabular}




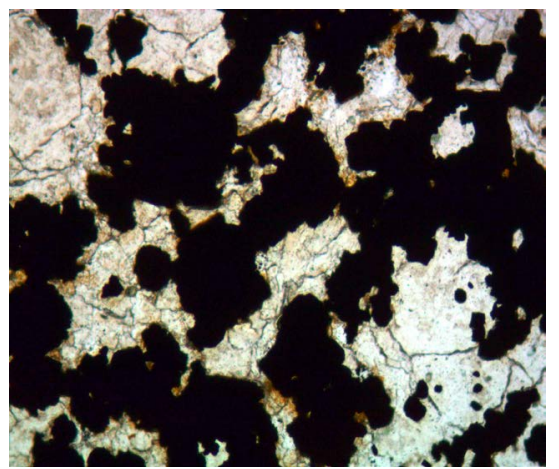

Figure 1. Sparsely disseminated magnetite ore $(\times 100)$.

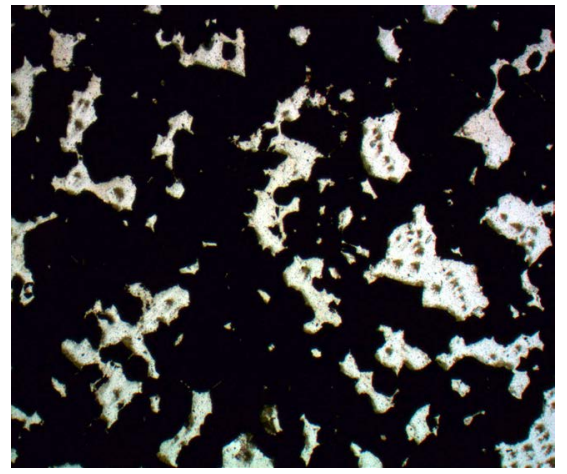

Figure 2. Sparsely disseminated magnetite ore $(\times 100)$.

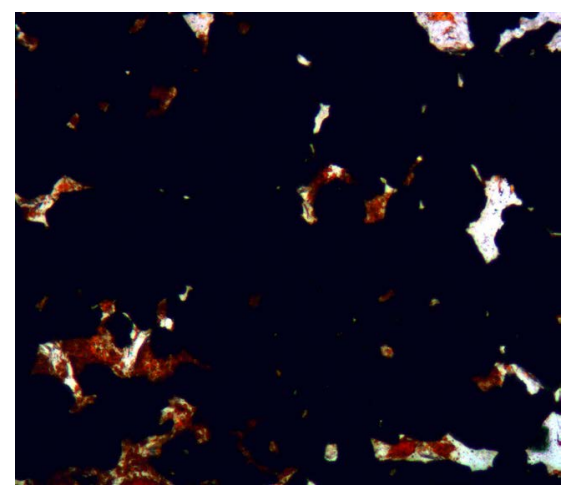

Figure 3. Densely disseminated magnetite rich ore $(\times 100)$.

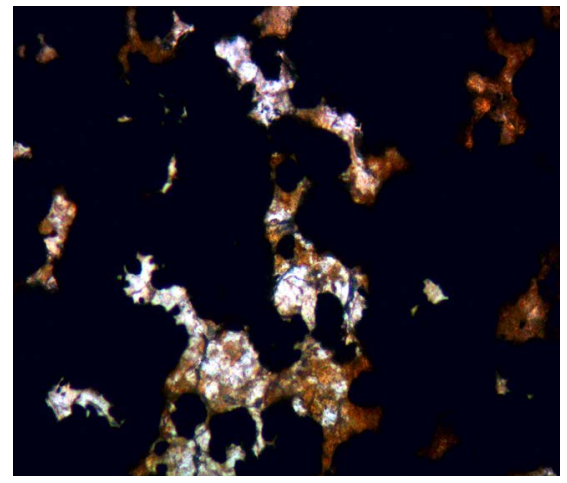

Figure 4. Densely disseminated magnetite rich ore $(\times 100)$. 
between $30 \%$ and $45 \%$ with about $1 \%-8 \%$ pyrite, while in densely disseminated magnetite rich ore, the content of magnetite is between $45 \%$ and $55 \%$ with about $5 \%$ pyrite. Both of them are considered as magnetite ore with high sulfur, and the main gangue minerals are serpentine, chlorite, talc, and phlogopite.

\subsubsection{The Structure of Ore}

The two types of ores are disseminated magnetite barren ore and densely disseminated magnetite rich ore. According to the content of magnetite, the ores can be divided into sparsely disseminated, disseminated, densely disseminated structure and gel or soil structure formed by weathering and eluviation.

The content of sparsely disseminated magnetite is between $15 \%$ and $30 \%$, which is distributed in gangue mineral aggregate in fine disseminated form. The content of disseminated magnetite is between $30 \%$ and $45 \%$, in which the magnetite appears to be mono crystal grain or polycrystal association texture and is distributed in gangue mineral aggregate in disseminated form [9]. The content of densely disseminated magnetite can reach between $45 \%$ and $55 \%$,where the magnetite is enriched to be irregular block mass, in which we can see closely connected magnetite crystals with little malcrystal fine grain gangue minerals.

The primary magnetite of gel or soil structure represented by weathering and eluviation form limonite, which appears to be secondary mineral aggregate in loose soil, porous or gel fine grain form.

The structure of ore can be generally divided into idiomorphic, sub-hederal and allotriomorphic granular texture, fiber like plastic texture and metasomatic pseudomorph texture. The magnetite and pyrite appear to be idiomorphic, sub-hederal and allotriomorphic granular texture, while gangue mineral serpentine which is metasomatic with primary olivine or augite minerals appears to be granular pseudomorph texture. Most serpentines are formed into fiber like and granular plastic texture by fine fiber like or radial aggregate and fine disseminated magnetite.

\subsubsection{The Occurrence of Main Minerals}

Magnetite occurs in two types of dissemination. One is sparsely disseminated and disseminated magnetite, and the other is densely disseminated magnetite. The magnetite in disseminated barren magnetite ores appear to be idiomorphic and sub-hederal middle-fine granular texture, fiber like plastic texture and metasomatic pseudo-morphic texture, while the magnetite in densely disseminated rich magnetite ores appear to be middle-coarse granular texture and fiber like plastic texture, and have simple contact ways and smooth boundaries between crystal grains [10] [11].

There is a big difference in hardness between magnetite and gangue mineral crystals in the process of crushing, making them easy to be liberated. However, we also find that fine grain gangue mineral malcrystals are wrapped in the magnetite crystals, leading to an incomplete liberation between magnetite and gangue minerals. 


\subsection{The Disseminated Size of Iron Minerals}

Sparsely disseminated and disseminated magnetite are dispersed in the gangue mineral aggregate such as serpentine, chlorite in the form of mono crystal or polycrystal association, and always poikilitic with serpentine, chlorite, and phlogopite. The grain size of magnetite is fine, mostly distributed between 0.021 $\mathrm{mm}$ and $0.104 \mathrm{~mm}$, while a small amount of magnetite appears to be threadlike pulse, disseminated along crack and grain boundary, which are shown in Figure 1 and Figure 2.

Densely disseminated magnetite appear to be idiomorphic, sub-hederal, and allotriomorphic granular aggregate; and the boundary between grains is clear. The grain size of magnetite is between $0.104 \mathrm{~mm}$ and $0.833 \mathrm{~mm}$, and they are always enriched into block mass with close intergrowth together. While those gangue minerals such as serpentine and chlorite seem to be extremely irregular fines and fiber like aggregate dissemination.

The range of whole magnetite size fraction is between $0.021 \mathrm{~mm}$ and 0.833 $\mathrm{mm}$, and mainly centered between $0.104 \mathrm{~mm}$ and $0.589 \mathrm{~mm}$. The average grain size is $0.182 \mathrm{~mm}$. Among the whole size fraction, $0.021 \mathrm{~mm}$ to $0.074 \mathrm{~mm}$ fine fraction covers $6.089 \%$, while $0.074 \mathrm{~mm}$ to $0.833 \mathrm{~mm}$ middle and coarse fraction covers $93.911 \%$, so we can see that coarse fraction magnetite is in the majority.

For iron industry, there is a very strict sulfur-content specification in magnetite concentrate, because pyrite is harmful mineral in iron ore. The observation under single polarizing microscope showed that the magnetite is closely combined with pyrite and pyrrhotine, and fine grain gangue mineral malcrystals are wrapped in the magnetite crystals. The size distribution of pyrite and pyrrhotine is finer than that of magnetite, mainly between $0.021 \mathrm{~mm}$ and $0.125 \mathrm{~mm}$, among which $0.051 \mathrm{~mm}$ size fraction covers $96.47 \%$.

In summary, middle coarse fraction is in the majority of magnetite and need to be concentrated under a condition of coarser grinding [12]. The grain size of pyrite is suitable for removal by flotation, so although the iron ore has a high sulfur, it can be seen from the analysis results of process mineralogy that it is easy to get low sulfur iron concentrate.

\subsection{The Mono Crystal Mineral Analysis}

By conducting magnetic separation and froth flotation to upgrade the ore under study, it was found that when the ore is ground to $60 \%$ finer than $0.076 \mathrm{~mm}$, iron concentrate of over $65 \%$ iron grade is obtained and the sulfur content of concentrate can be reduced to $0.35 \%$. When the ore is further ground to $92 \%$ finer than $0.051 \mathrm{~mm}$, iron concentrate of $67.12 \%$ iron grade is obtained and the sulfur content of concentrate can be reduced to $0.081 \%$. I was also found that after further fine grinding the iron grade of iron concentrate is stable at about $67.4 \%$ and the sulfur content is continuously reduced with the decline of mesh of grinding machine.

In order to discover why the iron concentrate grade cannot reach $68 \%$, we 
chose the mono crystal sample of magnetite for chemical analysis. The analysis results are listed in Table 3, showing that the total iron grade of this magnetite mono crystal mineral in the ores is less than $68 \%$.

The analysis results also exposed that magnesia content is the highest in all of impurities, getting to $2.60 \%$, while silica content is lower, only $1.29 \%$, which is beneficial to obtain iron concentrate containing low silicon.

In order to confirm the state of magnesia in magnetite mono crystal, X-ray diffraction analysis was conducted on magnetite mono crystal sample, and the result are shown in Figure 5. It is clear that existence of magnesioferrite is very obvious. The magnesium present in magnetite mono crystal could only be isomorphic replacement of iron in magnetite, therefore it is impossible to liberate magnesium from iron of magnesioferrite by the process of grinding. That is why it is not possible to get magnetite concentrate of over $68 \%$ grade by concentration processes.

\section{Conclusions}

The research on mineralogy showed that the Iranian iron ore is considered as magnetite ore with high sulfur and low silica. The main valuable mineral is magnetite and main gangue minerals are serpentine and chlorite.

The average size of magnetite is $0.182 \mathrm{~mm}$, a little coarse, and there is a big difference in hardness between magnetite and gangue minerals. For this reason, the magnetite is easy to liberate. The iron isomorphic replacement by magnesium in magnetite mono crystal will lead to a coarser grinding; thereby we can get an iron concentrate of about $67 \%$ iron grade by single magnetic separation.

It is known from the dissemination relationship of minerals, combination of minerals and nature of main minerals that the ore is worth being exploited. If we

Table 3. Chemical analysis results of the magnetite mono crystal.

\begin{tabular}{cccccccccc}
\hline element & $\mathrm{TFe}$ & $\mathrm{FeO}$ & $\mathrm{SiO}_{2}$ & $\mathrm{Al}_{2} \mathrm{O}_{3}$ & $\mathrm{CaO}$ & $\mathrm{MgO}$ & $\mathrm{S}$ & $\mathrm{P}$ & Loss \\
\hline Mass fraction (\%) & 67.36 & 21.71 & 1.29 & 1.25 & 0.55 & 2.60 & 0.068 & 0.014 & 1.78
\end{tabular}

Counts

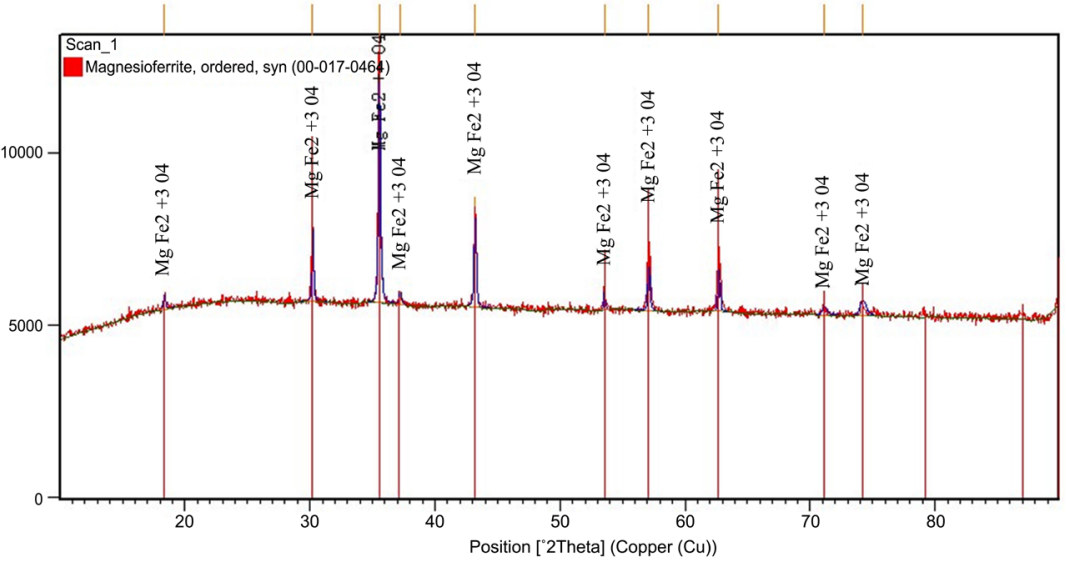

Figure 5. Image of X-ray diffraction analysis. 
want to get an iron concentrate of about $67 \%$ iron grade, how to reduce the sulfur is the key point.

Here are some suggestions on concentration experimental methods.

1) After one stage coarse grinding and single magnetic separation, the iron concentrate can develop a reverse flotation to reduce sulfur.

2) After two stage fine grinding and single magnetic separation, the sulfur of iron concentrate can be removed during the process of sintering.

We prefer to the former technique, because coarse grinding is of significance in reducing the power and reverse flotation to reduce sulfur can be more suitable for the sulfur content fluctuation of run-of-mined ore.

\section{Acknowledgements}

The authors would like to thank for the financial support by Liaoning Province Education Department of China (No.2017LNQN16) and they also would like to express their sincere appreciation to all the colleagues and staffs for their special assistance to the work.

\section{References}

[1] Mishra, P., Kumar, M.B., Kumar, M.P. and Mahanta, K. (2013) Influence of Microstructure on Beneficiation of Low-Grade Siliceous Manganese Ore from Orissa, India. Journal of Minerals and Materials Characterization and Engineering, 1, 80-84. https://doi.org/10.4236/jmmce.2013.13015

[2] Rao, D., Kumar, T., Rao, S., Prabhakar, S. and Raju, G. (2009) Mineralogy and Geochemistry of A Low Grade Iron Ore Sample from Bellary-Hospet Sector, India and Their Implications on Beneficiation. Journal of Minerals and Materials Characterization and Engineering, 8, 115-132. https://doi.org/10.4236/jmmce.2009.82011

[3] Yang, X., Laukkanen, J., Torppa, A. and Heino, N. (2016) Mineralogy and Beneficiation of Lamujärvi Syenites. Natural Resources, 7, 481-493. https://doi.org/10.4236/nr.2016.78041

[4] Mohanty, J., Jena, M. and Paul, A. (2012) Integrated Mineralogical Characterization of Banded Iron Ores of Orissa and Its Implications on Beneficiation. Journal of Minerals and Materials Characterization and Engineering, 11, 1133-1142. https://doi.org/10.4236/jmmce.2012.1112122

[5] Mineral Commodity Summaries (2013) U.S. Department of the Interior and U.S. Geological Survey, 85. http://minerals.usgs.gov/minerals/pubs/mcs/

[6] Zhou, L.G. (2007) Process Mineralogy. Metallurgical Industry Press, Beijing, 16-125.

[7] Qiu, Z.G. (1982) Mineralography. Geology Press, Beijing, 233-237.

[8] Liu, Z.C., Qiao, W.L. and An, Y.Y. (2012) Process Mineralogy of Sedimentary Hematite Ores from Weining, Guizhou. Guizhou Geology, 29, 62-67.

[9] Mineral Resources Institute of Chinese Academy of Geology. Identification of Metal Minerals by Microscope. Geology Press, Beijing, 67-69.

[10] Liu, X.W., Hua, Y.L. and Huang, X.M. (2012) Process Mineralogy of Some Gold Ore in Xinjiang. Acta Mineralogical Sinica, 32, 99-100.

[11] Li, J.P. and Wu, L.S. (2008) Iranian Geological Structure and Regional Metallogeny. 
Deposit Geology, 27, 120-121.

http://dx.doi.org/10.16111/j.0258-7106.2008.01.013

[12] Pei, M.S. and Liu, X.W. (2012) Main Progress of Process Mineralogy in Recent Ten Years. Bulletin of Mineral Geochemistry, 31, 210-217. 